\title{
Huzurevi Çalışanlarının Yaşlılara İlişkin Tutumlarının Belirlenmesi
}

\author{
Sevinç YILDIRIM ÜŞENMEZ*, Hatice KAYA**
}

$\ddot{O} \mathbf{z}$

Amaç: Bu araştırma huzurevi çalışanlarının yaşlılara ilişkin tutumlarının belirlenmesi amacıyla tanımlayıcı türde planlandl.

Yöntem: Araştırma, İstanbul ilinde bir huzurevinde 1 Kasım 2020 - 1 Ocak 2021 tarihleri arasında yürütüldü. Araştırmanın evrenini; huzurevinde çalışan $(\mathrm{N}=402)$, tüm sağlık çalışanları $(\mathrm{N}=198)$ ve idari personel $(\mathrm{N}=204)$ oluştururken; örneklemini 1 Kasım 2020-1 Ocak 2021 tarihleri arasında çalışan, araştırmanın amacı, içeriği, yöntemi konusunda bilgilendirme sonrası araştırmaya katılmayı kabul eden $(n=234)$, sağlık çalışanları $(n=147)$ ve idari personel $(n=87)$ oluşturdu.

Araştırma verileri, araştırmacı tarafından oluşturulan "Sosyodemografik Özellikler Bilgi Formu” ve Kogan (1961) tarafından geliştirilen "Yaşlılara Yönelik Tutum Ölçeği” kullanılarak toplandı. Araştırmada elde edilen veriler SPSS (Statistical Package for Social Sciences) Windows 22.0 programı kullanılarak analiz edildi. Verilerin değerlendirilmesinde tanımlayıcı istatistiksel yöntemlerden sayı, yüzde, ortalama, standart sapma kullanıldı. Normal dağılım gösteren verilerin karşılaştırılmasında t testi, tek yönlü varyans analizi ve regresyon analizi kullanıldı.

Bulgular: Araştırma kapsamına alınan çalışanların \%49,6’sı 40-49 yaş aralığında, \%56’sı erkek, \%79,5’i evli, \%34,6'sı lise mezunu, \%62,8’i sağlık bakım hizmetleri biriminde çalışmaktadır. Çalışanların \%58,5’i (sabah/akşam) vardiyalı olarak çalışmakta olup \%28,6'sı 10-15 yıldır kurumda çalışmaktadır. Çalışanların \%81,6'sı çekirdek aile tipine sahip olduğunu, \%50,9'u ailede 65 yaş üzeri birey bulunmadı̆̆ını, \%67,8'i ailede 65 yaş üzeri bireyle birlikte yaşamadığını belirtti. Çalışanların "olumsuz tutum” puan ortalaması

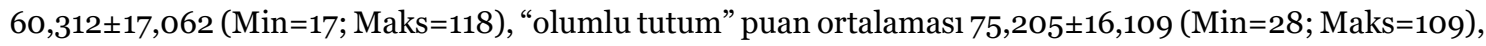
"toplam tutum" puan ortalaması 150,893 $\pm 22,210$ (Min=77; Maks=210) olarak saptandı. Kadınların olumsuz tutum puanları $(x=63,981)$, erkeklerin olumsuz tutum puanlarından $(x=57,428)$ yüksek bulundu $(t=2,965$; $\mathrm{p}=0.003<0.05)$. Evlilerin olumlu tutum puanları $(\mathrm{x}=74,285)$, bekârların olumlu tutum puanlarından $(\mathrm{x}=78,771)$ düşük bulundu $(\mathrm{t}=-1,727 ; \mathrm{p}=0.046<0.05)$. Sağlık bakım hizmetleri birimi çalışanlarının olumsuz tutum puanları, teknik işler biriminde çalışanlardan daha yüksek bulundu ( $<<0.05)$.Sağlık bakım hizmetleri biriminde çalışanların olumlu tutum puanları, diğer birimlerde çalışanlardan daha yüksek bulundu $(\mathrm{p}<0.05)$.

Sonuç: Araştırmada yaşlıya yönelik olumlu tutum yüksek bulunmakla birlikte, mevcut durumun devamı ve artması için olumlu tutumları destekleyen, geliştiren girişimlerin planlanması önemlidir. Olumlu tutumun geliştirilmesi ve kaliteli bakımın sağlanması çalışanların bilgi, beceri ve donanımını gerektirdiği için çalışanlara yönelik hizmet içi eğitimlerin planlanması, verilen eğitimlerin düzenli değerlendirilmesi gereklidir. Ayrıca yaşlı bireylere hizmet verecek çalışanların işe alım süreçlerinde mesleki bilgi, beceri,

Özgün Araştırma Makalesi (Original Research Article)

Geliș / Received: 26.07.2021 \& Kabul / Accepted: 14.12.2021

DOI: https://doi.org/10.38079/igusabder.974845

${ }^{*}$ Uzm. Hemşire, Doktora Öğrencisi, İstanbul Üniversitesi-Cerrahpaşa, Florence Nightingale Hemşirelik Fakültesi,

Hemşirelik Esasları Anabilim Dalı, İstanbul, Türkiye, E-posta: sevinc-yldrm@hotmail.com

ORCID https://orcid.org/oooo-0002-6187-9755

${ }^{* *}$ Prof. Dr., İstanbul Üniversitesi-Cerrahpaşa, Florence Nightingale Hemşirelik Fakültesi, Hemşirelik Esasları Anabilim Dalı, İstanbul, Türkiye, E-posta: haticeka@istanbul.edu.tr ORCID https://orcid.org/0000-0002-8427-0125

ETÍK BÍLDİRIM: Araştırmann yapılabilmesi için İstanbul Üniversitesi-Cerrahpaşa Sosyal ve Beşeri Bilimler Etik Kurulu'ndan 22/10/2020 tarihli ve 75632 sayılı izin alındı. Prof. Dr. Veli Duyan'dan ölçek kullanım izni alındı. 
donanımın yanı sıra yaşlıya yönelik tutumları açısından da bir değerlendirme sürecinden geçirilmeleri önem taşımaktadır.

Anahtar Sözcükler: Bakım evleri, huzurevi çalışanları, yaşl, tutum.

\title{
Determining the Attitudes of Nursing Home Employees Towards the Elderly
}

\begin{abstract}
Aim: This research was planned as descriptive for the purpose of determining the attitudes of nursing home employees towards the elderly.

Method: The research was carried out in a nursing home in Istanbul between 1 Kasim 2020 - 1 Ocak 2021. While all health $(\mathrm{N}=198)$ and administrative staff working $(\mathrm{N}=204)$ in the nursing home $(\mathrm{N}=402)$ constituted the universe of the research, the sample consisted of health $(\mathrm{n}=147)$ and administrative staff $(\mathrm{n}=87)$ who worked between 1 Kasım $2020-1$ Ocak 2021 and agreed to participate in the research $(n=234)$ after being informed about the purpose, content and method of the research.

Research data were collected by using the "Sociodemographic Characteristics Information Form" created by the researcher and the "Attitude Scale Towards The Elderly" developed by Kogan (1961). The data obtained in the research were analyzed using the SPSS (Statistical Package for Social Sciences) for Windows 22.0 program. In the evaluation of the data, number, percentage, average and standard deviation were used as descriptive statistical methods. T-test, one-way analysis of variance and regression analysis were used to compare normally distributed data.
\end{abstract}

Results: $49.6 \%$ of the employees included in the research are in the age range of $40-49,56 \%$ are male, $79.5 \%$ are married, $34.6 \%$ are high school graduates, $62.8 \%$ work in the health care unit. $58.5 \%$ of them work in shifts, $28.6 \%$ of them have been working in the institution for $10-15$ years. $81.6 \%$ of the employees stated that they have a nuclear family type, $50.9 \%$ of them stated that there is no person over 65 years of age in the family, $67.8 \%$ of them stated that they do not live with an individual over the age of 65 in the family. It is determined that "the negative attitude" average score of the employees was 60.312 \pm 17.062 (Min=17; Max=118), "the positive attitude" average score was 75,205 $\pm 16,109$ (Min=28; Max=109), "the total attitude" average score was $150.893 \pm 22.210(M i n=77 ; M a x=210)$. The negative attitude scores of women $(x=63,981)$ were higher than the negative attitude scores of male $(x=57,428)(t=2.965 ; p=0.003<0.05)$. Positive attitude scores of married people $(x=74,285)$ were lower than positive attitude scores of singles $(x=78,771)(t=-1.727$; $\mathrm{p}=0.046<0.05)$. The negative attitude scores of the employees of the health care services unit were higher than those of the employees in the technical affairs unit $(\mathrm{p}<0.05)$. The positive attitude scores of the employees in the health care unit were found higher than those of the employees in the other units $(\mathrm{p}<0.05)$.

Conclusion: In our study, positive attitudes towards the elderly are found high, it is important to plan initiatives that support and develop positive attitudes in order to continue and increase the current situation. Since developing a positive attitude and providing quality care requires the knowledge, skills and equipment of the employees, it is necessary to plan the in-service training for the employees and to evaluate the training provided regularly. In addition, it is important that employees who will serve elderly individuals must undergo an evaluation process in terms of their attitudes towards the elderly as well as their professional knowledge, skills and equipment in the recruitment process.

Keywords: Nursing homes, nursing home employees, elderly, attitude.

\section{Giriș}

Gelişen teknoloji ile birlikte, sağlık hizmetlerinin de gelişmesiyle yaşam süresi tüm dünyada artmıştır. Dünya Sağlık Örgütü (DSÖ) tarafından dünyada 6o yaş üstü insan sayısının 2000 yılında 600 milyon iken, 2025 yılında iki katına çıkacağını, 2050 yılında ise 2 milyarı bulacağını ve 80 yaşın üzerinde 400 milyon civarında insan olacağı tahmin edilmektedir ${ }^{1,2}$. 
Dünya nüfusunun yaşlanmasıyla ülkemizde de yaşam süresi artmakta ve nüfusumuz yaşlanmaya devam etmektedir. Yaşlı nüfus olarak tanımlanan 65 yaş ve üzerindeki nüfusun oranının 2025 yllında \%11,o, 2030 yllında \%12,9, 2040 yllında \%16,3, 2060 yllında \%22,6 ve 2080 yilında \%25,6 olacă̆ı öngörülmektedir. Ülkemizde yaşlı nüfus, son beş yılda \%22,5 artarak 2020 yılında 7 milyon 953 bin 555 kişi olmuştur3.

Artan yaşlı nüfus beraberinde yaşlı bireylerin problemlerini gündeme getirmektedir. Yaşlılık döneminde fiziksel aktivitelerinin azalması, artan sağlık sorunları, fiziksel kayıplar nedeniyle yaşlı bireylerin yaşadıkları toplum tarafından çok istenmeyen, bağımlı bir grup ve topluma yük olarak görülmelerine neden olmuştur4,5. Yaşlı bireyler sağlık ve bakım alanında geresinimlerin artması, psiko-sosyal problemler, üretken olmamaları, gelirin korunması, barınma gereksinimi gibi problemlerle karşılaşmaktadır ${ }^{6}$.

Günümüzde yaşlıların tüm gereksinimlerinin karşılanması ve bakım uygulamaları kamu ya da özel kuruluşlar aracılığıyla yapılmaktadır7. Huzurevleri bu noktada yaşlının alışkın olduğu aile ortamını devam ettirebilmeleri için modern toplumun bir gereği olarak ortaya çımış ve modern toplum bireylerine günlük yaşamlarını devam ettirebilmeleri için hizmet veren profesyonel yapıda kurumsal bir oluşumdur ${ }^{1,7}$. Yaşlı bireylerin bakımı noktasında profesyonel desteğin gerekliliğini ortaya çıkarmış olup beraberinde sağlık hizmeti iş gücünü ve sağlık bakımı gereksiniminin arttığını ortaya koymuştur ${ }^{1,7,8}$.

Yaşlıya karşı tutum ve davranışların oluşmasında bireylerin sosyokültürel yapıları ve gelenekleri önemli rol oynamaktadır7,9. Geleneksel aile yapısının yerini çekirdek aileye bırakması ve modernleşmenin hayatımıza girmesiyle yaşlı bireyler zihinsel işlevleri gerileyen, günlük yaşamını sürdürebilmek için başkalarının yardımına gereksinim duyan ekonomik veya sosyal katkı yerine topluma bir yük oldukları düşünülen bireyler olarak görülmeye başlanmıştırı,4.

Sağlık hizmetlerine artan talebi karşılamak için yaşlılara hizmet veren sağlık çalışanları, bakımın sunumunda önemli katkıları bulunmakta olup sağlık bakımı kalitesinin belirlenmesinde kilit rol oynamaktadır ${ }^{8,9}$. Sağlık çalışanlarının yaşlı bakımı ile ilgili eğitimi ve bilgisi kadar yaşlıya yönelik tutumu da yaşlıya vereceği bakımın kalitesinde etkilidir²,10,11. Yaşlı bireylere yönelik önyargıları, olumsuz değer ve inançları yaşlı bireylere karşı olumsuz tutum olarak yansımaktadır ${ }^{12}$. Özellikle sağllk ve bakım hizmeti verilen kurum çalışanlarının olumsuz tutumları yaşlılar için sağlık ve sosyal açıdan ciddi sonuçlara yol açmaktadır ${ }^{8,9}$. Böyle bir sonuç, sadece yaşlı bireylerin tedavi süreçlerini ve bakım kalitesini olumsuz etkilememekte, onları psikososyal bir yalnızlığa da itmektedir9. Bu nedenle huzurevinde kalan yaşlıların hem fiziksel hem psikososyal olarak kendilerini yeterli hissetmeleri açısından huzurevinde çalışmakta olan, yaşlı bireylerin öz bakım gereksinimlerini karşılayan ve sağlık hizmeti sunan sağlık çalışanlarının yaşlılık ve yaşlanma konusuna dikkatilerini çekmek ve bu konudaki farkındalıklarını arttırarak olumlu tutum

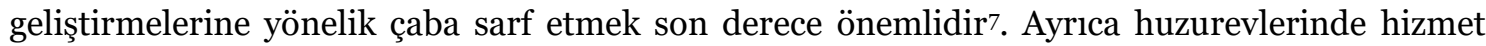
veren yaşlı bireylerle sosyal, mali yönden iletişim ve etkileşim halinde olan idari personellerin de olumlu tutum geliştirmelerinde farkındalık sağlamak adına çalışmaya dahil edilmişlerdir. Huzurevlerindeki yaşlıların daha kaliteli bakım almalarını sağlamak için çalışanların tutumlarının belirlenmesi önem taşımaktadır.

$\mathrm{Bu}$ araştırma huzurevi çalışanlarının yaşlılara ilişkin tutumlarının belirlenmesi amacıyla tanımlayıcı türde planlandı. Bu amaç doğrultusunda aşağıdaki sorulara yanıt arandı.

- Huzurevi çalışanlarının sosyodemografik özellikleri nelerdir?

- Huzurevi çalışanlarının yaşlılara ilişkin tutum düzeyi nedir? 
- Huzurevi çalışanlarının sosyodemografik özelliklerine göre yaşlılara ilişkin tutumları arasında farklılık var mıdır?

\section{Gereç ve Yöntem}

Araştırmanın Tipi: Bu araştırma tanımlayıcı türde planlandı.

Araştırmanın Yapıldığı Yer ve Zaman: Araştırma, İstanbul ilinde bir huzurevinde 1 Kasım 2020 -1 Ocak 2021 tarihleri arasında gerçekleştirildi.

Araştırmanın Evren ve Örneklemi: Araştırmanın evrenini, huzurevinde çalışan ( $\mathrm{N}=402)$ tüm sağllk $(\mathrm{N}=198)$ ve idari personel $(\mathrm{N}=204)$ oluştururken; örneklem seçimine gidilmemiş tam sayım yöntemi ile evrenin tamamına ulaşılması hedeflenmiştir. 1 Kasım 2020 - 1 Ocak 2021 tarihleri arasında çalışan, araştırmanın amacı, içeriği, yöntemi konusunda bilgilendirme sonrası araştırmaya katılmayı kabul eden $(n=234)$, sağlık çalışanları $(n=147)$ ve idari personel $(n=87)$ oluşturdu. Araştırmaya katılmayan çalışanların katılmama nedenleri; izinli (idari izin, doğum izni, ücretsiz izin, vb.) olmaları ya da anket formunu doldurmak istememeleridir.

Veri Toplama Araçları: Araştırma verilerinin toplanmasında; Sosyodemografik Özellikler Bilgi Formu ve Yaşlılara Yönelik Tutum Ölçeği kullanıldı.

Sosyodemografik Özellikler Bilgi Formu: Araştırma örneklemine alınan çalışanlara ait tanıtıcı bilgileri içeren bu form, araştırmacı tarafından yaşlılara yönelik tutumları etkileyebileceği düşünülen faktörler göz önüne alınarak oluşturuldu. Formda, çalışanların yaşı, cinsiyeti, eğitim durumu, medeni durumu, aile büyükleri ile birlikte yaşama gibi bilgiler yer aldı.

Yaşlılara Yönelik Tutum Ölçeği: Yaşlılara Yönelik Tutum Ölçeği Kogan (1961) tarafından insanların yaşlılara yönelik tutumlarını ölçmek amacıyla geliştirilmiştir. Duyan ve Gelbal tarafından (2010) Türkçe geçerlilik ve güvenirlik çalışması yapılmış olup cronbach alpha güvenirlik değeri olumlu tutum alt ölçeği için 0.789 , olumsuz tutum alt ölçeği için 0.794 ve Yaşlılara Yönelik Tutum Ölçeği'nin tamamı için 0.840 olarak saptanmıştır. Yaşlılara Yönelik Tutum Ölçeği'nde ilk 17 madde olumsuz tutum alt ölçeğine, 18-34 arasında yer alan maddeleri ise olumlu tutum alt ölçeğine aittir. Ölçeğe verilen yanıtlar 1-kesinlikle katılmıyorum, 2katılmıyorum, 3-biraz katılmıyorum, 4-biraz katılıyorum, 5-katıllyorum ve 6-kesinlikle katılıyorum şeklinde 6'lı Likert tipindedir ${ }^{13}$. Bu araştırma için cronbach alpha olumlu tutum alt ölçeği için 0,877 , olumsuz tutum alt ölçeği için 0,856 ve Yaşlılara Yönelik Tutum Ölçeğinin tamamı için 0,858 olarak belirlendi.

Verilerin İstatistiksel Analizi: Araştırmada elde edilen veriler SPSS (Statistical Package for Social Sciences) for Windows 22.0 programı kullanılarak analiz edildi. Verilerin değerlendirilmesinde tanımlayıcı istatistiksel yöntemleri olarak sayı, yüzde, ortalama, standart sapma kullanıldı. Normal dağılım gösteren verilerin karşılaştırılmasında t testi, tek yönlü varyans analizi ve regresyon analizi kullanıldı. Araştırma değişkenlerinin normal dağılım gösterip göstermediğini belirlemek üzere Kurtosis (Basıklık) ve Skewness (Çarpıklık) değerleri incelendi. Kurtosis değeri "olumsuz tutum" puanı 0,196, "olumlu tutum" puanı 0,714, "toplam tutum" puanı 0,654 saptandı. Skewness değeri ise "olumsuz tutum" puanı -0,045, "olumlu tutum” puanı -0,916, “toplam tutum” puanı 0,165 saptandı.

İlgili literatürde, değişkenlerin basıklık çarpıklık değerlerine ilişkin sonuçların +1.5 ile $-1.5,+2.0$ ile -2.0 arasında olması normal dağılım olarak kabul edilmektedir ${ }^{14,15}$. İki bağımsız grup arasında niceliksel sürekli verilerin karşılaştırılmasında t-testi, ikiden fazla bağımsız grup arasında niceliksel sürekli verilerin karşılaştırılmasında Tek yönlü (Oneway) Anova testi kullanıldı. Anova 
testi sonrasında farklılıkları belirlemek üzere tamamlayıcı post-hoc analizi olarak Scheffe testi kullanıldı.

Araştırmanın Etik Yönü: Araştırmanın yapılabilmesi için İstanbul Üniversitesi-Cerrahpaşa Sosyal ve Beşeri Bilimler Etik Kurulu'ndan (Tarih: 22/10/2020-Sayı: 75632), araştırmanın gerçekleştirileceği kurumdan izin ve Prof. Dr. Veli Duyan'dan ölçek kullanım izni alındı. Araştırmaya katılanlara araştırmanın amacı, alınan bilgilerin açılanan amaç dışında kullanılmayacağı, sadakat-gizlilik ilkesine bağlı kalınacağı anlatılıp araştırmaya katılmayı kabul eden gönüllü çalışanların yazılı ve sözlü onamı alındı.

\section{Bulgular}

Tablo 1. Çalışanların sosyodemografik özellikleri (n=234)

\begin{tabular}{|c|c|c|}
\hline Sosyodemografik Özellikler & Frekans(n) & Yüzde (\%) \\
\hline \multicolumn{3}{|l|}{ Yaş } \\
\hline $20-29$ & 26 & 11,1 \\
\hline $30-39$ & 66 & 28,2 \\
\hline $40-49$ & 116 & 49,6 \\
\hline 50 ve üzeri & 26 & 11,1 \\
\hline \multicolumn{3}{|l|}{ Cinsiyet } \\
\hline Kadın & 103 & 44,0 \\
\hline Erkek & 131 & 56,0 \\
\hline \multicolumn{3}{|l|}{ Medeni Durum } \\
\hline Evli & 186 & 79,5 \\
\hline Bekar & 48 & 20,5 \\
\hline \multicolumn{3}{|l|}{ Ĕgitim Durumu } \\
\hline İlköğretim & 71 & 30,3 \\
\hline Lise & 81 & 34,6 \\
\hline Ön Lisans & 28 & 12,0 \\
\hline Lisans ve üzeri & 54 & 23,1 \\
\hline \multicolumn{3}{|l|}{ Birim } \\
\hline Sağlık Bakım Hizmetleri Birimi & 147 & 62,8 \\
\hline Teknik İşler Birimi & 32 & 13,7 \\
\hline Diğer (Mali işler, Personel işleri, Güvenlik, Mutfak) & 55 & 23,5 \\
\hline \multicolumn{3}{|l|}{ Çalışma Şekli } \\
\hline Gündüz & 97 & 41,5 \\
\hline Vardiyalı & 137 & 58,5 \\
\hline \multicolumn{3}{|l|}{ Çalışma Yılı } \\
\hline o ay - 4 yll & 43 & 18,4 \\
\hline $5-9$ yll & 51 & 21,8 \\
\hline $10-15$ yll & 67 & 28,6 \\
\hline $16-19$ yll & 35 & 15,0 \\
\hline
\end{tabular}




\begin{tabular}{|l|l|l|}
\hline 20 yıl ve üzeri & 38 & 16,2 \\
\hline Aile Tipi & 191 & 81,6 \\
\hline Çekirdek Aile & \multicolumn{2}{l|}{} \\
\hline Geniş Aile & 43 & 18,4 \\
\hline Ailede 65 Yaş Üzeri Birey Varlığı & \multicolumn{2}{l|}{} \\
\hline Evet & 115 & 49,1 \\
\hline Hayır & 119 & 50,9 \\
\hline Ailede 65 Yaş Üzeri Bireyle Birlikte Yaşama & \multicolumn{2}{|l|}{} \\
\hline Evet & 37 & 32,2 \\
\hline Hayır & 78 & 67,8 \\
\hline
\end{tabular}

Tablo 1'de çalışanların \%49,6'sının (n=116) 40-49 yaş grubunda, \%56,o'sının (n=131) erkek olduğu görüldü. \%79,5'inin ( $\mathrm{n}=186)$ evli, \%34,6'sının ( $\mathrm{n}=81)$ lise mezunu, \%62,8'inin (n=147) sağlık bakım hizmetleri biriminde, \%58,5’inin(n=137) vardiyalı çalıştığı saptandı. Çalışanların \%28,6'sının ( $\mathrm{n}=67)$ 10-15 yıldır kurumda çalıştığ 1 \% \%1,6'sının $(\mathrm{n}=191)$ çekirdek aile yapısına sahip olduğu, \%50,9'unun (n=119) ailesinde 65 yaş üzeri birey olmadığı ve \%67,8’inin(n=78)65 yaş üzeri bireyle yaşamadıkları saptandı.

Tablo 2. Yaşlılara ilişkin tutum ölçeği puan ortalamaları (n=234)

\begin{tabular}{|l|l|l|l|l|l|l|}
\hline Tutum Puanları & n & Ort & SS & Min. & Maks. & Alpha \\
\hline Olumsuz Tutum & 234 & 60,312 & 17,062 & 17,000 & 118,000 & 0,856 \\
\hline Olumlu Tutum & 234 & 75,205 & 16,109 & 28,000 & 109,000 & 0,877 \\
\hline Toplam Tutum & 234 & 150,893 & 22,210 & 77,000 & 210,000 & 0,858 \\
\hline
\end{tabular}

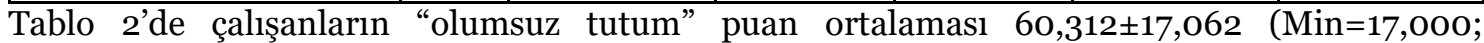
Maks=118,000), "olumlu tutum" puan ortalaması 75,205 $\pm 16,109$ (Min=28,000; Maks=109,000), "toplam tutum" puan ortalaması 150,893 $\pm 22,210$ (Min=77,000; Maks=210,000) olarak saptandı.

Tablo 3. Çalışanların demografik özelliklerine göre yaşlılara ilişkin tutum ölçeği puan ortalamaları $(\mathrm{n}=234)$

\begin{tabular}{|l|l|l|l|l|}
\hline Demografik Özellikler & $\mathbf{N}$ & Olumsuz Tutum & Olumlu Tutum & Toplam Tutum \\
\hline Yaş & & Ort \pm SS & Ort \pm SS & Ort \pm SS \\
\hline $20-29$ & 26 & $58,154 \pm 11,202$ & $75,731 \pm 12,654$ & $153,577 \pm 19,188$ \\
\hline $30-39$ & 66 & $59,424 \pm 17,548$ & $76,121 \pm 15,201$ & $152,697 \pm 24,289$ \\
\hline $40-49$ & 116 & $61,052 \pm 17,384$ & $76,129 \pm 15,831$ & $151,078 \pm 20,478$ \\
\hline 5 o ve üzeri & 26 & $61,423 \pm 19,649$ & $68,231 \pm 21,157$ & $142,808 \pm 26,114$ \\
\hline Test & & $\mathrm{F}=0,305$ & $\mathrm{~F}=1,852$ & $\mathrm{~F}=1,431$ \\
\hline p değeri & & $\mathrm{p}=0,822$ & $\mathrm{p}=0,138$ & $\mathrm{p}=0,235$ \\
\hline Cinsiyet & & Ort $\pm \mathrm{SS}$ & $\mathrm{Ort} \pm \mathrm{SS}$ & Ort $\pm \mathrm{SS}$ \\
\hline Kadın & 103 & $63,981 \pm 15,605$ & $76,029 \pm 14,124$ & $148,049 \pm 18,035$ \\
\hline Erkek & 131 & $57,428 \pm 17,654$ & $74,557 \pm 17,539$ & $153,130 \pm 24,848$ \\
\hline Test & & $\mathrm{t}=2,965$ & $\mathrm{t}=0,693$ & $\mathrm{t}=-1,745$ \\
\hline
\end{tabular}




\begin{tabular}{|c|c|c|c|c|}
\hline p değeri & & $\mathrm{p}=0,003$ & $\mathrm{p}=0,489$ & $\mathrm{p}=0,071$ \\
\hline Medeni Durum & & Ort $\pm \mathrm{SS}$ & Ort $\pm \mathrm{SS}$ & Ort $\pm \mathrm{SS}$ \\
\hline Evli & 186 & $59,323 \pm 16,863$ & $74,285 \pm 16,771$ & $150,962 \pm 22,447$ \\
\hline Bekar & 48 & $64,146 \pm 17,465$ & $78,771 \pm 12,765$ & $150,625 \pm 21,492$ \\
\hline Test & & $t=-1,754$ & $t=-1,727$ & $t=0,094$ \\
\hline p değeri & & $\mathrm{p}=0,081$ & $\mathrm{p}=0,046$ & $\mathrm{p}=0,925$ \\
\hline Ĕ̆itim Durumu & & Ort \pm SS & Ort $\pm \mathrm{SS}$ & Ort $\pm \mathrm{SS}$ \\
\hline İlköğretim & 71 & $56,845 \pm 19,661$ & $75,296 \pm 19,262$ & $154,451 \pm 23,696$ \\
\hline Lise & 81 & $61,691 \pm 16,978$ & $73,889 \pm 16,641$ & $148,198 \pm 24,013$ \\
\hline Ön Lisans & 28 & $61,429 \pm 15,208$ & $77,571 \pm 13,014$ & $152,143 \pm 19,248$ \\
\hline Lisans ve üzeri & 54 & $62,222 \pm 13,889$ & $75,833 \pm 11,849$ & $149,611 \pm 18,364$ \\
\hline Test & & $\mathrm{F}=1,427$ & $\mathrm{~F}=0,407$ & $\mathrm{~F}=1,096$ \\
\hline p değeri & & $\mathrm{p}=0,236$ & $\mathrm{p}=0,748$ & $\mathrm{p}=0,352$ \\
\hline
\end{tabular}

Tablo 3'te çalışanların olumsuz tutum, olumlu tutum, toplam tutum puanları yaş ve eğitim durumu değişkenine göre anlamlı farklılık göstermedi ( $p>0.05)$. Kadınların olumsuz tutum puanları $(\mathrm{x}=63,981)$, erkeklerin olumsuz tutum puanlarından $(\mathrm{x}=57,428)$ yüksek bulundu $(\mathrm{t}=2,965 ; \mathrm{p}=0.003<0.05)$. Çalışanların olumlu tutum ve toplam tutum puanları cinsiyet değişkenine göre anlamlı farklılık göstermedi ( $>0.05)$. Evlilerin olumlu tutum puanları $(\mathrm{x}=74,285)$, bekarların olumlu tutum puanlarından $(\mathrm{x}=78,771)$ düşük bulundu $(\mathrm{t}=-1,727$; $\mathrm{p}=0.046<0.05)$. Çalışanların olumsuz tutum ve toplam tutum puanları medeni durum değişkenine göre anlamlı farklılık göstermedi ( $p>0.05$ ).

Tablo 4. Çalışanların çalışma ve aile ile ilgili özelliklerine göre yaşlılara ilişkin tutum ölçeği puan ortalamaları $(\mathrm{n}=234)$

\begin{tabular}{|l|l|l|l|l|}
\hline $\begin{array}{l}\text { Çalışma ve Aile ile İlgili } \\
\text { Özellikler }\end{array}$ & $\mathbf{n}$ & $\begin{array}{l}\text { Olumsuz } \\
\text { Tutum }\end{array}$ & $\begin{array}{l}\text { Olumlu } \\
\text { Tutum }\end{array}$ & $\begin{array}{l}\text { Toplam } \\
\text { Tutum }\end{array}$ \\
\hline Birim & & Ort \pm SS & Ort \pm SS & Ort $\pm S S$ \\
\hline Sağlık Bakım Hizmetleri Birimi & 147 & $62,531 \pm 16,164$ & $77,116 \pm 12,984$ & $150,585 \pm 19,608$ \\
\hline Teknik İşler Birimi & 32 & $53,875 \pm 18,514$ & $75,875 \pm 20,226$ & $158,000 \pm 33,393$ \\
\hline $\begin{array}{l}\text { Diğer (Mali işler, Personel işleri, } \\
\text { Güvenlik, Mutfak) }\end{array}$ & 55 & $58,127 \pm 17,610$ & $69,709 \pm 19,697$ & $147,582 \pm 20,181$ \\
\hline Test & & $\mathrm{F}=4,076$ & $\mathrm{~F}=4,387$ & $\mathrm{~F}=2,289$ \\
\hline p değeri & & $\mathrm{p}=0,018$ & $\mathrm{p}=0,013$ & $\mathrm{p}=0,104$ \\
\hline PostHoc & & $1>2(\mathrm{p}<0.05)$ & $1>3(\mathrm{p}<0.05)$ & \\
\hline Çalışma Şekli & & Ort $\pm \mathrm{SS}$ & $\mathrm{Ort} \pm \mathrm{SS}$ & $\mathrm{Ort} \pm \mathrm{SS}$ \\
\hline Gündüz & 97 & $58,443 \pm 17,565$ & $73,083 \pm 19,351$ & $150,639 \pm 24,293$ \\
\hline Vardiyalı (Sabah / Akşam) & 137 & $61,635 \pm 16,634$ & $76,708 \pm 13,219$ & $151,073 \pm 20,699$ \\
\hline Test & & $\mathrm{t}=-1,413$ & $\mathrm{t}=-1,703$ & $\mathrm{t}=-0,147$ \\
\hline p değeri & & $\mathrm{p}=0,159$ & $\mathrm{p}=0,112$ & $\mathrm{p}=0,883$ \\
\hline Çalışma Yılı & & Ort $\pm \mathrm{SS}$ & Ort $\pm \mathrm{SS}$ & Ort $\pm \mathrm{SS}$ \\
\hline o ay - 4 yll & 43 & $57,140 \pm 16,332$ & $78,302 \pm 14,791$ & $157,163 \pm 22,496$ \\
\hline 5 - 9 yll & 51 & $62,353 \pm 18,365$ & $77,588 \pm 14,196$ & $151,235 \pm 23,317$ \\
\hline
\end{tabular}




\begin{tabular}{|l|l|l|l|l|}
\hline $10-15$ yl & 67 & $62,537 \pm 14,790$ & $74,597 \pm 15,887$ & $148,060 \pm 20,798$ \\
\hline $15-19$ yll & 35 & $60,143 \pm 16,830$ & $75,343 \pm 15,289$ & $151,200 \pm 25,886$ \\
\hline 20 yll ve üzeri & 38 & $57,395 \pm 19,723$ & $69,447 \pm 19,865$ & $148,053 \pm 18,464$ \\
\hline Test & & $\mathrm{F}=1,120$ & $\mathrm{~F}=1,946$ & $\mathrm{~F}=1,296$ \\
\hline $\mathrm{p}$ değeri & & $\mathrm{p}=0,348$ & $\mathrm{p}=0,104$ & $\mathrm{p}=0,272$ \\
\hline Aile Tipi & & Ort $\pm \mathrm{SS}$ & Ort $\pm \mathrm{SS}$ & Ort $\pm \mathrm{SS}$ \\
\hline Çekirdek Aile & 191 & $60,655 \pm 15,974$ & $75,571 \pm 15,631$ & $150,916 \pm 21,315$ \\
\hline Geniş Aile & 43 & $58,791 \pm 21,396$ & $73,581 \pm 18,191$ & $150,791 \pm 26,098$ \\
\hline Test & & $\mathrm{t}=0,646$ & $\mathrm{t}=0,731$ & $\mathrm{t}=0,033$ \\
\hline $\mathrm{p}$ değeri & & $\mathrm{p}=0,593$ & $\mathrm{p}=0,466$ & $\mathrm{p}=0,973$ \\
\hline $\begin{array}{l}\text { Ailede 65 Yaş Üzeri Birey } \\
\text { Varlığı }\end{array}$ & & $\mathrm{Ort} \pm \mathrm{SS}$ & $\mathrm{Ort} \pm \mathrm{SS}$ & $\mathrm{Ort} \pm \mathrm{SS}$ \\
\hline Evet & 115 & $58,296 \pm 18,722$ & $75,122 \pm 15,664$ & $152,826 \pm 22,408$ \\
\hline Hayır & 119 & $62,261 \pm 15,112$ & $75,286 \pm 16,592$ & $149,025 \pm 21,948$ \\
\hline Test & & $\mathrm{t}=-1,785$ & $\mathrm{t}=-0,078$ & $\mathrm{t}=1,311$ \\
\hline $\mathrm{p}$ değeri & & $\mathrm{p}=0,075$ & $\mathrm{p}=0,938$ & $\mathrm{p}=0,191$ \\
\hline $\begin{array}{l}\text { Ailede 65 Yaş Üzeri Bireyle } \\
\text { Birlikte Yaşama }\end{array}$ & & Ort $\pm \mathrm{SS}$ & $\mathrm{Ort} \pm \mathrm{SS}$ & Ort $\pm \mathrm{SS}$ \\
\hline Evet & 37 & $58,135 \pm 22,860$ & $76,216 \pm 14,806$ & $154,081 \pm 25,568$ \\
\hline Hayır & 78 & $58,372 \pm 16,572$ & $74,603 \pm 16,122$ & $152,231 \pm 20,896$ \\
\hline Test & & $\mathrm{t}=-0,063$ & $\mathrm{t}=0,514$ & $\mathrm{t}=0,412$ \\
\hline p değeri & & $\mathrm{p}=0,950$ & $\mathrm{p}=0,608$ & $\mathrm{p}=0,681$ \\
\hline
\end{tabular}

Tablo 4'te çalışanların olumsuz tutum, olumlu tutum, toplam tutum puanları çalışma şekli, çalışma yılı, aile tipi, ailede 65 yaş üzeri birey varlığı ve ailede 65 yaş üzeri bireyle birlikte yaşama değişkenine göre anlamlı farklılık göstermedi ( $\mathrm{p}>0.05)$. Çalışanların olumsuz tutum puanları çalıştıkları birim değişkenine göre anlamlı farklılık gösterdi $(F=4,076 ; p=0.018<0.05)$. Sağlık bakım hizmetleri birimi çalışanlarının olumsuz tutum puanları, teknik işler biriminde çalışanlardan daha yüksek bulundu ( $\mathrm{p}<0.05)$. Çalışanların olumlu tutum puanları, birim değişkenine göre anlamlı farklılık gösterdi $(\mathrm{F}=4,387 ; \mathrm{p}=0.013<0.05)$. Sağlık bakım hizmetleri biriminde çalışanların olumlu tutum puanları, diğer birimlerde çalışanlardan daha yüksektir (p<0.05). Çalışanların toplam tutum puanları, çalışılan birim değişkenine göre anlamlı farklılık göstermedi ( $\mathrm{p}>0.05)$.

Tablo 5. Yaşlılara ilişkin tutumu etkileyen faktörler

\begin{tabular}{|c|c|c|c|c|c|c|c|}
\hline Bağımlı Değişken & Bağımsız Değişken & B & $\mathbf{T}$ & $\mathbf{P}$ & $\mathbf{F}$ & Model (p) & $\mathbf{R}^{2}$ \\
\hline \multirow{3}{*}{ Olumsuz Tutum } & Sabit & 71,201 & 19,338 & 0,000 & \multirow{3}{*}{4,874} & \multirow{3}{*}{0,008} & \multirow{3}{*}{0,032} \\
\hline & Cinsiyet & $-5,917$ & $-2,568$ & 0,011 & & & \\
\hline & Birim & $-0,901$ & $-0,979$ & 0,329 & & & \\
\hline \multirow{3}{*}{ Olumlu Tutum } & Sabit & 74,446 & 20,575 & 0,000 & \multirow{3}{*}{5,791} & \multirow{3}{*}{0,004} & \multirow{3}{*}{$0,04 c$} \\
\hline & Medeni Durum & 4,333 & 1,695 & 0,091 & & & \\
\hline & Birim & $-2,423$ & $-2,916$ & 0,004 & & & \\
\hline
\end{tabular}


Tablo 5'te yaşlılara ilişkin tutumu etkileyen faktörleri belirlemek üzere tek değişkenli analizler sonucunda ilişkili bulunan değişkenler üzerinden regresyon analizi yapıldı. Ölçeğin genel toplam puanı tek değişkenli analizler sonucunda ilişkisiz $(\mathrm{p}<0,05)$ bulunduğundan regresyon analizi yapılmadı. Cinsiyet ve çalışılan birim değişkeni ile olumsuz tutum arasındaki neden sonuç ilişkisini belirlemek üzere yapılan regresyon analizi anlamlı bulundu $(F=4,874 ; p=0,008<0.05)$. Olumsuz tutum düzeyindeki toplam değişim \%3.2 oranında cinsiyet, birim değişkeni tarafından açıklanmaktadır $\left(R^{2}=0,032\right)$. Erkek olmak olumsuz tutum düzeyini azaltmaktadır $(\beta=-5,917)$. Çalışlan birim değişkeni olumsuz tutum düzeyini etkilememektedir ( $\mathrm{p}=0.329>0.05)$. Medeni durum ve çalışılan birim değişkeni ile olumlu tutum arasındaki neden sonuç ilişkisini belirlemek üzere yapılan regresyon analizi anlamlı bulundu $(\mathrm{F}=5,791 ; \mathrm{p}=0,004<0.05)$. Olumlu tutum düzeyindeki toplam değişim \%4 oranında medeni durum, birim değişkeni tarafından açlklanmaktadır $\left(\mathrm{R}^{2}=0,040\right)$. Medeni durum olumlu tutum düzeyini etkilememektedir $(\mathrm{p}=0.091>0.05)$. Teknik işler ve diğer birimde çalışıyor olmak olumlu tutum düzeyini azaltmaktadır $(\beta=-2,423)$.

\section{Tartışma}

Ülkemizde yaşlı nüfus oranındaki artış toplumumuzun yaşlandığını göstermekte olup yaşlılık ile ilgili problemleri beraberinde getirmektedir. Yaşlılıkla birlikte bireyin günlük yaşam aktivitelerini yerine getirmedeki yetersizlikler ve yaşlı bireyin bakıma ihtiyaç duyması ile sağlık, sosyo kültürel, toplumsal olarak barınma imkânı gibi birçok alanda yaşlı bireyi etkileyen sorunlar ortaya çıkmaktadır. Genç nüfusun köyden kente göç etmesiyle yaşlı bireylerin yalnız kalması, eşlerden birin kaybı, çocukların çalışıyor olması, çocukların yanlarında olmaması ya da bakmaması gibi birçok neden yaşlı bireylerin sağlık ve bakım gereksinimlerinin karşılanmasında huzurevlerinin önemli yer tuttuğu görülmektedir. Yaşlı bireyin yaşadığı ve alışık olduğu aile ortamını sağlaması açısından huzurevlerinde çalışanların yaşlı bireylere yönelik tutum ve davranışları önem taşımaktadır.

Huzurevi çalışanlarının yaşlılara ilişkin tutumlarını belirlemek amacıyla gerçekleştirilen araştırmada önemli sonuçlar elde edildi. Çalışanların olumlu tutum puanlarının olumsuz tutum puanlarından yüksek olduğu saptandı. Yapılan araştırmalarda yaşlılara yönelik hem olumlu, hem olumsuz tutumlar birlikte görülmektedir. Ünalan ve ark. (2012)'nın geriatri merkezinde yaptığı

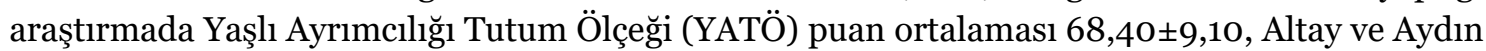
(2014)'nın hemşirelik öğrencileriyle yaptığı araştırmada Yaşlı Ayrımcılığı Tutum Ölçeği (YATÖ)

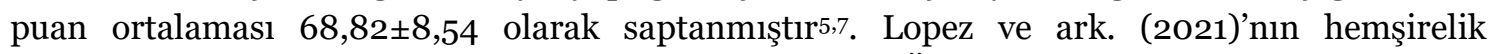
öğrencileriyle yaptığı araştırmada Yaşlılara Yönelik Tutum Ölçeği toplam puanı ortalaması 131,04 olarak olumlu belirtilmiştiri' ${ }^{16}$. Hemşirelerle yapılan Kang ve ark. (2011)'nın araştırmasında Demanslı Yaşlılara Yönelik Tutumlar Ölçeği puanları orta düzeyde olumlu, yine hemşirelerle yapılan Mellor, Chew ve Greenhill (2007)'nin araştırmasında Yaşllara Yönelik Tutum Ölçeği puanları olumlu saptanmıştır ${ }^{17,18}$. Kalaycı ve ark. (2017)'nın 18 araştırmayı değerlendirdikleri sistematik derlemelerinde 17 araştırmada sağlık çalışanları ve öğrencilerin yaşlılara yönelik tutumlarının olumlu olduğu, sistematik derlemede bulunan 1 araştırma ise Köse ve ark. (2015)'ın hemşirelik, tıp ve sağlık astsubay öğrencileriyle yaptığı araştırmada yaşlılara yönelik tutumlarının olumsuz olduğu belirtilmiştir 9 . Araştırmada olumlu tutumun daha yüksek çıkması gibi birçok faktör ile ilişkilendirilirken yaşlı bireylerin bakımı konusunda geleneklerine bağlı, büyüklerine sahip çıkan bir toplum içinde yetişmenin etkili olduğunu düşündürmektedir.

Araştırmada huzurevi çalışanlarının yaşlılara yönelik tutumları yaşa göre anlamlı farklılık göstermedi. Zhang ve Sun (2019)'un yaşlı bakıcılarıyla yaptığı araştırma sonucu da benzerdir ${ }^{19}$. Literatür incelendiğinde Kaçan ve ark. (2018)'nın toplumda yaşayan bireylerle, Leung ve ark. 
(2011)'nın hekimlerle yaptığı araştırmalarda yaşla birlikte olumlu tutumun arttı̆g 1 sonucu elde edilmiştir ${ }^{20,21}$. Bu sonuçlardan farklı olarak Fırat ve ark. (2020)'nın Kars, Artvin, Ağrı, Erzincan, Ardahan ve Iğdır il merkezinde yaşayan bireylerle, Başaran (2018)'ın üniversite öğrencileriyle yaptığı araştırmalarda ise yaşla birlikte olumsuz tutumun arttığı belirlenmiştir ${ }^{22,23}$.

Cinsiyet değişkeninde kadın çalışanların olumsuz tutum puanları erkeklerin olumsuz tutum yüksek bulundu. Soyuer ve ark. (2010)'nın, McLafferty ve Morrison (2004)'in hemşirelik öğrencilerinde yaptığı araştırmada cinsiyetler arasında yaşlı tutumu ile ilgili farklılık bulunmadığı belirtilirken cinsiyetlere göre farklılık bulunduğunu bildiren araştırmalar da mevcuttur 24,25. Ünalan ve ark. (2012)'nın geriatri merkezindeki çalışanlarla yaptığı araştırmada kadın çalışanların yaşlıya yönelik olumsuz ayrımcılık puan ortalamaları, erkek çalışanlara göre anlamlı düzeyde yüksek bulunmuştur7. Mandıracıoğlu ve Çam (2004)'ın huzurevi çalışanlarıyla yaptığı araştırmada yaşlılara hizmet veren kadın personelin erkeklerden daha fazla sorun yaşadı ̆̆ı, Zhang ve Sun (2019)'un yaşlı bakıcılarıyla yaptığı araştırmada kadın çalışanların olumsuz algılarının yüksek olduğu saptanmıştır ${ }^{19,26}$. Bu araştırma bulgusunun aksine Fırat ve ark. (2020)'nın toplum üzerinde yaptığı araştırmada cinsiyet değişkeni yaşlıya yönelik tutum açısından incelendiğinde, kadınların erkeklerden daha olumlu bir tutum sergilediği belirlenmiştir ${ }^{22}$. Ayrıca Altay ve Aydın (2014), Adıbelli ve ark. (2013), Usta ve ark. (2012)'nın hemşirelik öğrencileriyle, Adelman ve ark. (1991)'nın ise hekimlerle yaptığı araştırmalar da kadınların erkeklerden daha olumlu tutum sergilediği gösterilmektedir5,27,28,29. Araştırma bulgusuna göre yaşlıların öz bakım gereksinimlerinin karşılanması sırasında fiziksel gücün gerekmesi, kadın çalışanların erkek çalışanlardan daha fazla zorlanmalarına ve baş etmekte güçlük yaşamalarına sebep olduğunu düşündürmektedir.

Evlilerin olumlu tutum puanları, bekârların olumlu tutum puanlarından düşük saptandı. Fırat ve ark. (2020)'nın toplum üzerinde yaptığı araştırmasında da benzer sonuç elde edilmiştir ${ }^{22}$. Bu sonuç bekar bireylerin evli ve çocuk sahibi olan bireylere oranla sorumluluklarının daha az olması nedeniyle yaşlı bireylere daha kolay zaman ayırabildiğini ve empati yaparak daha olumlu bir tutum sergilediğini düşündürmektedir.

Araştırmada eğitim durumuna göre yaşlılara yönelik tutum anlamlı farklılık göstermedi. Frrat ve ark. (2020)'nın toplum üzerinde yaptıkları araştırmada, üniversite ve üzeri eğitim seviyesine sahip bireylerin diğer az eğitimli bireylere oranla yaşlıya yönelik tutumları daha olumlu bulunmuştur ${ }^{22}$. Leung ve ark. (2011)'nın hekimlerle, Usta ve ark. (2012)'nın hemşirelik öğrencileriyle yaptığ 1 araştırmalarda eğitim düzeyinin etkili olduğu belirtilmiştir ${ }^{21,28}$. Benzer şekilde Tuncer (2018)'in sağlık çalışanlarıyla yaptığı araştırmasında, eğitim düzeyi ile yaşlı ayrımcığı arasında olumlu yönde anlamlı ilişki olduğu belirlenirken Ünalan ve ark. (2012)'nın geriatri merkezinde çalışanlarla yaptığı araştırmasında ise eğitim düzeyi arttıkça yaşlılara yönelik olumsuz tutumun arttığı sonucuna ulaşılmıştır30,7.

Sağlık bakım hizmetleri birimi çalışanlarının olumsuz tutum puanlarının, teknik işler biriminde çalışanlardan daha yüksek olduğu belirlendi. Sağlık çalışanlarının yaşlı bireylerin üstesinden gelmesi zor olan öz bakım gereksinimlerinde etkin rol almasının, mevcut kronik hastalıklarla baş etmeye çalışmasının, COVID-19 pandemisi nedeniyle yatılı sistemde ve fazla mesai saatleriyle çalışılmasının olumsuz tutum puanlarında etkili olabileceğini düşündürmektedir.

Çalışanların yaşlılara yönelik tutumları aile tipi değişkenine göre farklılık göstermedi. Fırat ve ark. (2020)'nın araştırmasında aile tipinin yaşlılığa yönelik tutuma etki etmediği bulunmuştur²2. Ünalan ve ark. (2012)'nın araştırmasında geniş aile yapısına sahip olanların çekirdek aile yapısına sahip olanlara göre yüksek olmakla beraber gruplar arasında anlamlı fark bulunmamıştır7. Geniş aile yapısına sahip bireylerin aile büyükleriyle birlikte yaşaması, paylaşımlarının fazla olması 
geleneklere ve kültüre sahip çıkılmasında ve yaşlı bireylere daha olumlu tutumlarla yaklaşılmasında etkili olabileceğini düşündürmektedir.

Çalışanların yaşlılara yönelik tutumları ailede 65 yaş üzeri birey varlığı ve 65 yaş üzeri bireyle birlikte yaşama durumuna göre farklılık saptanmadı. Bu araştırmanın aksine Ünalan ve ark. (2012)'nın araştırmasında yaşamın herhangi bir döneminde yaşlılarla birlikte yaşamış olanlarda olumlu tutumların gelişme oranı anlamlı düzeyde yüksek bulunmuştur7.

\section{Sonuç ve Öneriler}

Araştırma sonucunda huzurevi çalışanlarının yaşlıya yönelik olumlu tutumları yüksek bulunmakla birlikte cinsiyete, medeni duruma ve çalışılan birime göre istatistiksel olarak anlamlı farklılıklar saptandı. Erkek olmanın olumsuz tutum düzeyini azalttığı belirlendi. Medeni durumun olumlu tutum düzeyini etkilemediği saptandı. Çalışılan birimin olumsuz tutum düzeyini etkilemediği ve teknik işler ile diğer birimde çalışıyor olmanın olumlu tutum düzeyini azalttığı saptandl.

Bu sonuçlar doğrultusunda;

- Huzurevi çalışanlarının iş yükü, iş doyumu ve çalışma saatlerinin değerlendirilmesi,

- Çalışma saatlerinin düzenlenerek iş yükünün azaltılması,

- Hem iş doyumunu hem olumlu tutumları arttıracağı düşünülen yaşlı bireylerle paylaşımların sadece iş odaklı olmaması ve birlikte sosyal aktivitelere katılım sağlanması,

- Tüm huzurevi çalışanları için olumlu tutum oluşumunu destekleyen ve geliştiren düzenli aralıklarla hizmet içi eğitimlerin planlanması ve uygulanması önerilmektedir.

\section{KAYNAKLAR}

1. Artan T, Irmak HI. Huzurevindeki yaşlıların huzurevinde yaşlanmaya ilişkin bakış açılarının değerlendirilmesi: İstanbul Bahçelievler, Zeytinburnu ve Sultangazi huzurevi örneği. Toplum ve Sosyal Hizmet. 2018;29(2):51-70.

2. Wilson A, KurrleIan SE, Wilson I. Understanding Australian medical student attitudes towards older people. Australian of Journal Ageing. 2018;37(2):93-98. doi: 10.1111/ajag.12495.

3. Türkiye İstatistik Kurumu. İstatistiklerle Yaşlılar, 2020. https://data.tuik.gov.tr/Bulten/Index?p=Istatistiklerle-Yaslilar-2020-37227. Yayınlanma tarihi 18 Mart 2021. Erişim tarihi 2 Nisan 2021.

4. Çunkuş N, Yiğitoğlu GT, Akbaş E. Yaşlılık ve toplumsal dışlanma. Geriatrik Bilimler Dergisi. 2019;2(2):58-67.

5. Altay B, Aydın T. Hemşirelik öğrencilerinin yaşlı ayrımcılığına ilişkin tutumlarının değerlendirilmesi. Hemşirelikte Ĕ̆itim ve Araştırma Dergisi. 2014;12(1): 11-18.

6. Demirel MN. Yaşlılarda Psiko-Sosyal Güçlükler ve Sosyal Hizmet İhtiyacı [yüksek lisans tezi]. Ankara, Türkiye: Başkent Üniversitesi, Sosyal Bilimler Enstitüsü Sosyal Hizmet Anabilim Dalı; 2017.

7. Ünalan D, Soyuer F, Elmalı F. Geriatri merkezi çalışanlarında yaşlı tutumunun değerlendirilmesi. Kafkas Tip Bilimleri Dergisi. 2012;2(3):115-120. 
8. Yun-e L, Norman IJ, White AE. Nurses' attitudes towards older people; a systematic review. Int. Nursing Stud. 2013;50:1271-1281.

9. Kalaycı I, Yazıcı SÖ, Özkul M, Helvacı G. Sağlık çalışanları ve öğrencilerinin yaşlılara yönelik tutumları: Sistematik derleme. Adnan Menderes Üniversitesi Sağlık Bilimleri Fakültesi Dergisi. 2017;2(1):21-30.

10. Ferrario CG, Freeman FJ, Nellett G, ScheelJ. Changing nursing students 'attitudes about aging: an argument for the successful aging paradigm. Educ.Gerontol. 2007:34(1):51-66.

11. Zehirlioğlu L, Yönt HG, Bayat E, Günay B. Hemşirelerin yaşlılara yönelik tutumları ve etkileyen faktörlerin belirlenmesi. Yıldırım Beyazıt Üniversitesi Sağlık Bilimleri Fakültesi Hemşirelik E-Dergisi. 2015;3(1):10-18.

12. Aşiret GD, Kaymaz TT, Canpolat Ö, Kapucu S. Hemşirelerin yaşlıya ilişkin tutumları. Hemşirelik Araştırma Geliştirme Dergisi. 2015;17(1):10-20.

13. Duyan V, Gelbal S. Yaşlılara Yönelik Tutum Ölçeği’nin bir grup üniversite öğrencisi üzerinde Türkçeye uyarlama çalışması. Turkish Journal of Geriatrics. 2013;16(2):202-209.

14. Tabachnick BG, Fidell LS. Using Multivariate Statistics. 6th ed. Boston: Pearson Education; 2013.

15. George D, Mallery M. SPSS for Windows Step by Step: A Simple Guide and Reference 17.0 Update.10th ed. Boston: Pearson Education; 2010.

16. López-Hernández L, Martínez-Arnau FM, Castellano-Rioja E, Botella-Navas M, Pérez-Ros P. Factors affecting attitudes towards older people in undergraduate nursing students. Healthcare (Basel, Switzerland). 2021;9(9):1231. https://doi.org/10.3390/healthcaregog1231.

17. Kang Y, Moyle W, Venturato L. Korean nurses' attitudes towards older people with dementia in acute care settings. International journal of older people nursing. 2011;6(2):143-152. https://doi.org/10.1111/j.1748-3743.2010.00254.x.

18. Mellor P, Chew D, Greenhill J. Nurses' attitudes toward elderly people and knowledge of gerontic care in a multi purpose health service (MPHS). The Australian journal of advanced nursing : a quarterly publication of the Royal Australian Nursing Federation. 2007;24(4): 37-41.

19. Zhang H, Sun H. Knowledge, attitude and self-efficacy of elderly caregivers in Chinese nursing homes: a cross-sectional study in Liaoning Province. BMJ open. 2019;9(11): e029869. https://doi.org/10.1136/bmjopen-2019-029869.

20. Kaçan H, Dibekli E, Akkan K. Toplumda yaşayan bireylerin yaşlı ayrımcılığı tutum düzeylerinin incelenmesi. EIRJ. 2018;11:8-15.

21. Leung S, LoGiudice D, Schwarz J, Brand C. Hospital doctors' attitudes towards older people. Internal Medicine Journal. 2011;41:308-314.

22. Fırat M, Kanbay Y, Gökben BD, Öztürk Ş. Yaşlılık inançları ve yaşlıya yönelik tutumların incelenmesi: çok merkezli bir çalışma. EJONS. 2020;4(14):266-278.

23. Başaran Ö. Süleyman Demirel Üniversitesi Son Sınıf Lisans Öğrencilerinin Yaşlı Ayrımcılığına İlişkin Tutumları ve Etkileyen Etmenler [tıpta uzmanlık tezi]. Isparta, Türkiye: Süleyman Demirel Üniversitesi, Tıp Fakültesi Halk Sağlı̆̆ı Anabilim Dalı; 2018. 
24. Soyuer F, Ünalan D, Güleser N, Elmalı E. Sağlık Meslek Yüksekokulu öğrencilerinin yaşlı ayrımcılığına ilişkin tutumları ve bu tutumların bazı demografik değişkenlerle ilişkisi. Mersin Üniversitesi Sağlık Bilimleri Dergisi. 2010;3(2):20-5.

25. McLafferty I, Morrison F. Attitudes towards hospitalized older adults. J Adv Nurs. 2004;47(4):446-53.

26. Mandıracıoğlu A, Çam O. Huzurevi çalışanlarının sorunları ve çalışanlar hakkında görüşleri. Turk J Geriatrics. 2004;7:29-32.

27. Adıbelli D, Türkoğlu N, Kılıç D. Öğrenci hemşirelerin yaşlılığa ilişkin görüşleri ve yaşlılara karşı tutumları. DEUHYO ED. 2013;6:2-8.

28. Usta YY, Demir Y, Yonder M, Yıldız A. Nursing students' attitudes towards ageism in Turkey. Archives of Gerontology and Geriatrics. 2012;54:90-93.

29. Adelman RD, Greene MG, Charon R. Issues in physician- elderly patient interaction. Ageing and Society. 1991;11:127-148.

30. Tuncer F. Birinci Basamak Sağlık Hizmeti Veren Kurumlarda Çalışan Sağlık Personelinin Yaşlı Ayrımcılığına İlişkin Tutumlarının Belirlenmesi [yüksek lisans tezi]. Kayseri, Türkiye: Erciyes Üniversitesi, Sağlık Bilimleri Enstitüsü Hemşirelik Anabilim Dalı; 2018. 